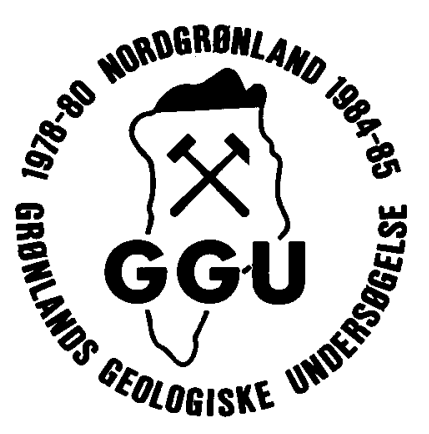

\title{
Cambrian platform stratigraphy in the Warming Land - Freuchen Land region, North Greenland
}

\author{
John S. Peel and Stephen C. Wright
}

\begin{abstract}
Cambrian platform strata in the Warming Land - Freuchen Land region are briefly described and correlated with sequences in more easterly and westerly areas of North Greenland. The name Ryder Gletscher Group is proposed for a mainly carbonate sequence (thickness about $640 \mathrm{~m}$ ) in the Warming Land - Wulff Land area of Early Cambrian - Early Ordovician age. Dominant lithologies are dark burrow-mottled dolomites and pale, cryptalgal laminites, but micrites, thin shales and thin sandstones are common in higher beds. Six formations are recognised but not formally described.
\end{abstract}

J. S. P., Grønlands Geologiske Undersфgelse, Øster Voldgade 10, DK-1350 Copenhagen K, Denmark.

S. C. W., Department of Earth Sciences, University of Oxford, Parks Road, Oxford OX1 3PR, U.K.

Occurrences of Cambrian strata in northern Greenland have recently been reviewed by Peel (1982). The carbonate dominated platform sequence is best known in Peary Land, central North Greenland, to the east (Ineson \& Peel, 1980, in press), and in Inglefield Land and Daugaard-Jensen Land to the west (summary by Peel \& Christie, 1982). Sequences in intervening areas from Freuchen Land to Warming Land (fig. 1) have only been briefly examined prior to the 1984 field season (Dawes, 1976; Hurst \& Peel, 1979; Peel, 1980).

Cambrian stratigraphy described in the western Peary Land area by Ineson \& Peel (1980) can be employed westward to the head of Nordenskiöld Fjord without difficulty, and constituent formations of the Brønlund Fjord and Tavsens Iskappe Groups are readily distinguished. To the south-west of the Nordenskiöld Fjord - Jungersen Gletscher line, however, this stratigraphy cannot be recognised, and it has proved necessary to introduce a new nomenclature. A new group, the Ryder Gletscher Group, is described here, with type area in south-west Wulff Land (fig. 2A), and its six constituent formations are briefly characterised.

The transition zone between the two sequences is marked by a thick unit of pale weathering dolomites with which formations of both sequences intergrade. The unit is imperfectly known on account of inaccessible exposures in the steep fjord and valley walls, but appears to be composed mainly of dolomite grainstones prograding approximately from south to north. The unit may prove to be a new formation of the Brønlund Fjord Group (fig. 2B) comparable in its lithology and setting to the Paralleldal Formation of central Peary Land (Ineson \& Peel, in press; see also fig. 2B). 


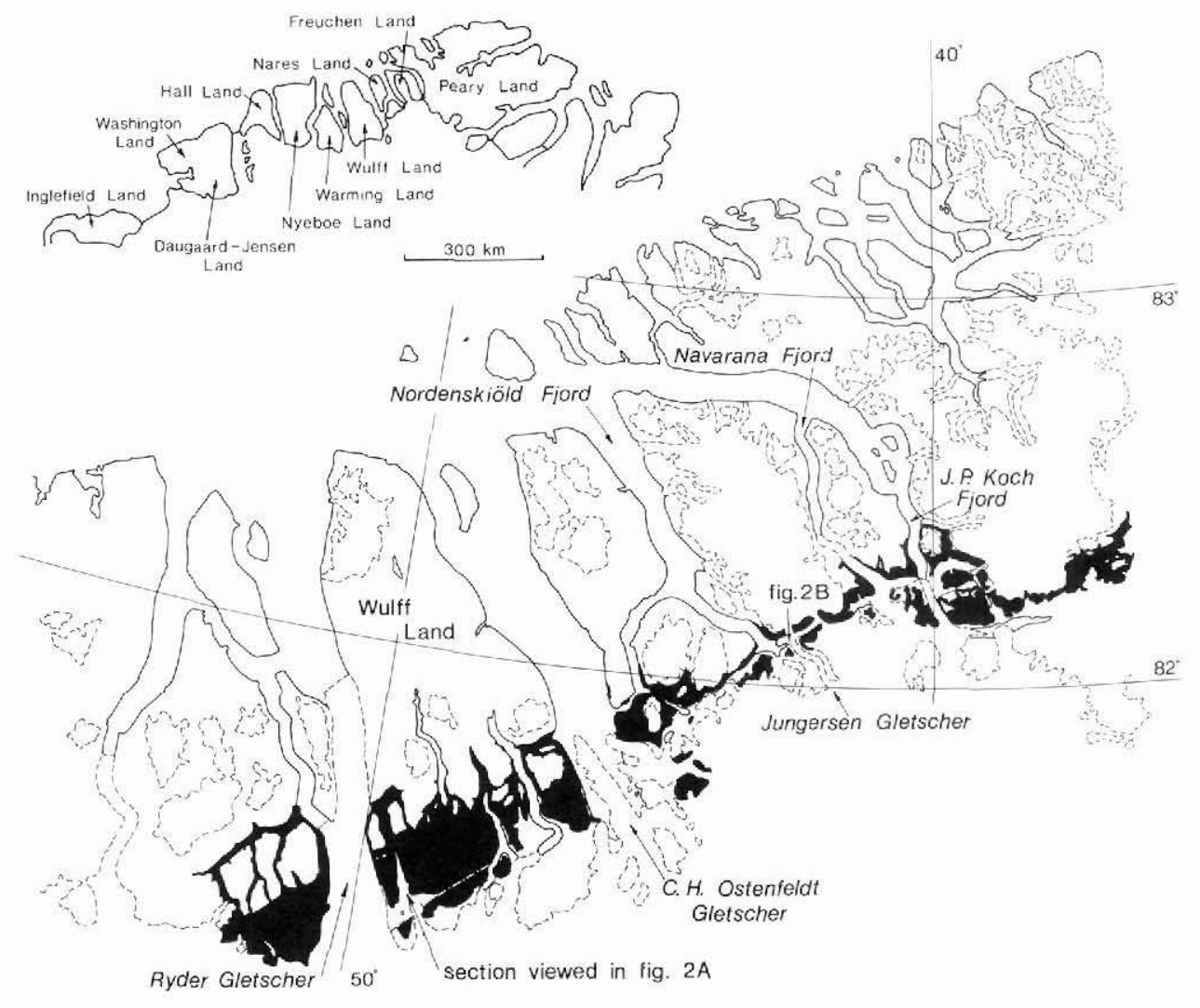

Fig. 1. Outcrop of the Ryder Gletscher Group and the laterally equivalent Brønlund Fjord and Tavsens Iskappe Groups in North Greenland (black). The latter two groups outcrop principally to the north-east of the Nordenskiöld Fjord - Jungersen Gletscher line, while the Ryder Gletscher Group outcrops to the south-west of this line.

In southern Freuchen Land, the carbonates of the Brønlund Fjord Group overlie clastics of the Buen Formation with apparent conformity (fig. 2B). A red-stained breccia at the junction between the Buen Formation and the generally pale well bedded carbonates of the underlying Portfjeld Formation may be of karstic origin. Strata below the Portfjeld Formation are not exposed in this area.

To the south-west of Nordenskiöld Fjord, the Ryder Gletscher Group overlies the Buen Formation (fig. 2A), but the latter overlies a chaotic breccia interpreted as a debris flow equivalent to the bedded Portfjeld Formation sequence to the north-east.

\section{Ryder Gletscher Group}

Name. After Ryder Gletscher (fig. 1), the glacier separating Wulff Land and Warming Land which was named by the Second Thule Expedition (1916-18). Cliffs on the eastern side of 

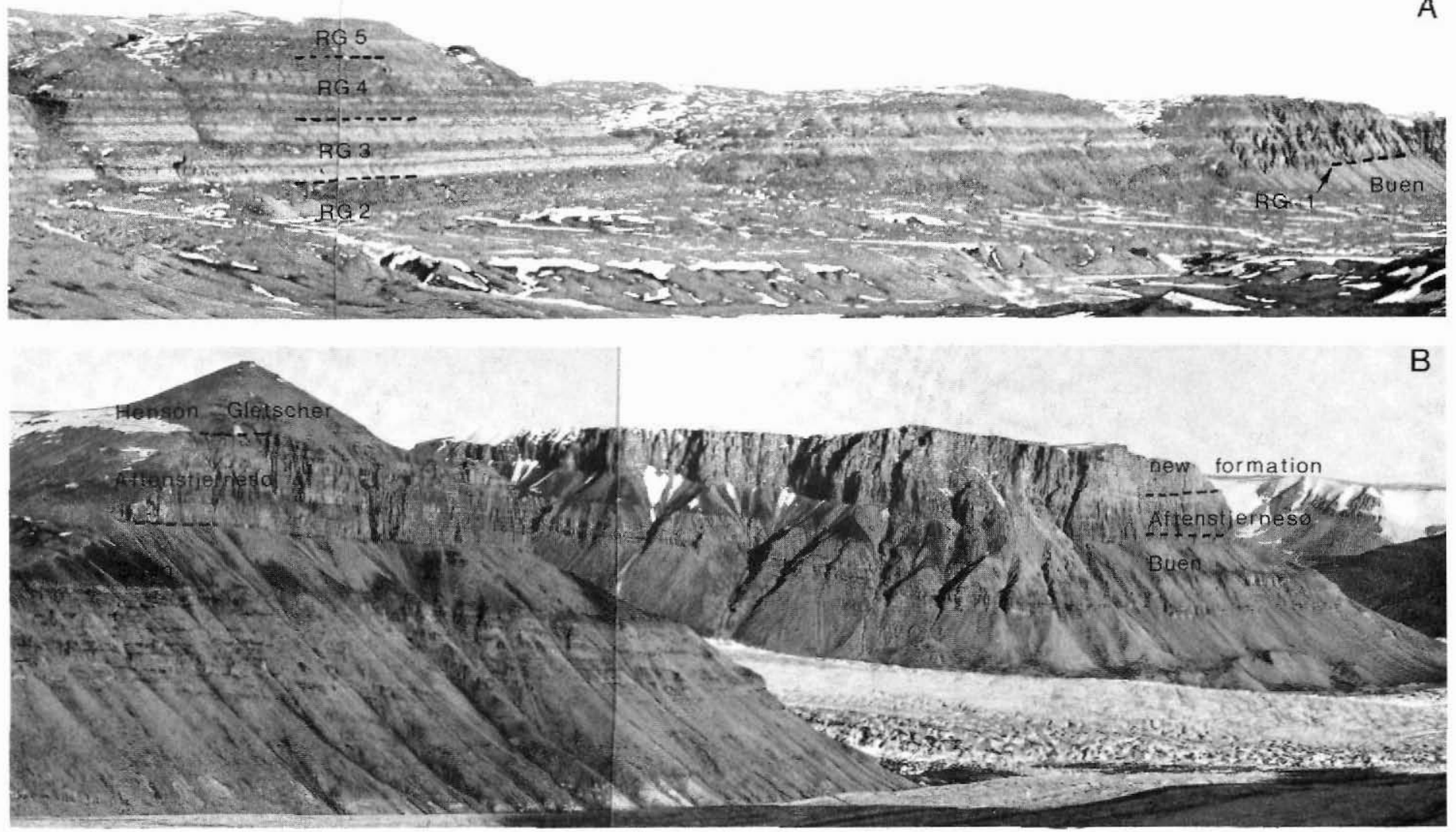

Fig. 2. A. Formations RG1-RG5 of the Ryder Gletscher Group overlying the recessive Buen Formation in south-west Wulff Land, viewed from the northwest (see fig. 1). See text for formation thicknesses. B. Lower sandstones and upper, dark, recessive shales of the Buen Formation overlain by mainly carbonates of the Brønlund Fjord Group at Jungersen Gletscher, viewed from the north (see fig. 1). Recessive carbonates and shales of the Henson Gletscher Formation thin rapidly to the west, across the glacier, where a new, undescribed formation of pale cliff-forming dolomite overlies the Aftenstjernes $ø$ Formation. Sequence at left approaches $550 \mathrm{~m}$ total thickness. 
Ryder Gletscher exhibit a fully exposed, but inaccessible section through the formations of the group.

Type area. South-west Wulff Land. An almost continuous and accessible section through the constituent formations of the group is exposed in the prominent north-south valley lying parallel to, and a few kilometres east of, Ryder Gletscher (figs 1 \& 2A).

History. The Ryder Gletscher Group corresponds approximately to the 'undifferentiated Cambrian carbonate unit' of Peel (1980). Limestones of formation RG1, the lowest unit of the group, were not recognised by Peel, although thin limestone beds of similar lithology which occur within the underlying Buen Formation were seen at that time. Hurst \& Peel (1979) briefly described a few metres of dolomite from the lower part of the group in southeast Wulff Land and compared the sequence to the Brønlund Fjord Group of Peary Land (Peel, 1979; Ineson \& Peel, 1980). The boundary between this carbonate sequence and the underlying Buen Formation, illustrated by Hurst \& Peel (1979, fig. 6), corresponds to the lower boundary of the Ryder Gletscher Group. Geologists of the Greenarctic Consortium (Dawes, 1976) recorded a sequence of clastics and fossiliferous Lower Cambrian carbonates in south-east Wulff Land which can now be interpreted as Buen Formation and the lower part of the Ryder Gletscher Group.

Dominant lithology. The Ryder Gletscher Group is a mainly carbonate sequence, although silts and thin sandstones are conspicuous at higher levels. Dolomites dominate and vary in lithology from dark and burrow-mottled to pale, cryptalgal laminites. Limestones occur principally as a basal bioclastic unit, which is locally micritic, and as micrites within the more lithologically varied upper part of the group.

Thickness. About $640 \mathrm{~m}$.

Boundaries. Sediments of the Ryder Gletscher Group rest conformably upon clastics of the Buen Formation. Limestones of similar lithology to the basal formation (RG1) occur as thin beds within the shales, siltstones and thin sandstones of the Buen Formation, but the boundary can be drawn where limestone development becomes persistent. On a larger scale, the cliff-forming carbonates of the Ryder Gletscher Group form a conspicuous mapping unit above the dark, recessive upper part of the Buen Formation. The upper boundary of the group in its type area is drawn at the base of the Permin Land Formation, and is discussed by Bryant \& Smith (1985). The latter formation is a distinctive white sandstone unit recognised throughout most of the outcrop area of the Ryder Gletscher Group. In its extreme eastern development, near the head of Nordenskiöld Fjord, the Ryder Gletscher Group appears to be overlain by inaccessible, pale weathering dolomites assigned to the Fimbuldal Formation of the Tavsens Iskappe Group (Ineson \& Peel, in press; formation T1 of Ineson \& Peel, 1980).

Distribution. The group outcrops in a broad belt from south-east Warming Land in the west to Nordenskiöld Fjord in the east.

Subdivision. Six formations, informally termed formations RG1-RG6, in ascending order, are referred to the Ryder Gletscher Group in its type area. 


\begin{tabular}{|c|c|c|c|c|c|c|c|}
\hline $\begin{array}{c}\text { Daugaard - Jensen } \\
\text { Land }\end{array}$ & & $\begin{array}{l}\text { ing Land } \\
\text { Iff Land }\end{array}$ & & $\begin{array}{l}\text { Freuchen Land \& } \\
\text { western Peary Land }\end{array}$ & & \multirow{2}{*}{\multicolumn{2}{|c|}{ Ordovician }} \\
\hline \multirow{3}{*}{ Cass Fjord Fm } & \multirow{3}{*}{ 气े } & \multirow{2}{*}{ RG 6} & \multirow{4}{*}{ 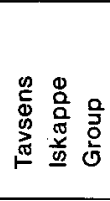 } & \multirow{2}{*}{ Perssuaq Gletscher Fm } & \multirow{2}{*}{$T_{3}$} & & \\
\hline & & & & & & U. & \\
\hline & & Rी & & Holm Dal Fm & $T_{2}$ & & \\
\hline \multirow{3}{*}{ Telt Bugt Fm } & $\bar{\Phi}$ & $-?$ & & Fimbuldal Fm & $\mathrm{T}_{1}$ & \multirow{3}{*}{ M. } & \\
\hline & $\frac{0}{\mathscr{0}}$ & RG 4 & & Ekspedition Bræ $\mathrm{Fm}$ & 4 & & \\
\hline & \multirow{3}{*}{ 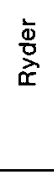 } & & & Sydpasset Fm & 3 & & $\stackrel{0}{20}$ \\
\hline \multirow[b]{2}{*}{ Kastrup Elv Fm } & & RG 3 & 훙응 운 & Henson Gletscher Fm & 2 & & $\tilde{0}$ \\
\hline & & $\begin{array}{l}\mathrm{RG} 2- \\
\mathrm{RG} 1=\end{array}$ & & Aftenstjernes $\varnothing \quad \mathrm{Fm}$ & 1 & \multirow{3}{*}{ L. } & \\
\hline \multirow[t]{2}{*}{ Humboldt Fm } & \multicolumn{5}{|c|}{ Buen Formation } & & \\
\hline & \multicolumn{5}{|c|}{ Portfjeld Formation } & & \\
\hline
\end{tabular}

Fig. 3. Cambrian stratigraphy and correlations in North Greenland. The numerical sequences to the right of the figure are the informal formation designations employed by Ineson \& Peel (1980); corresponding formation names are from Ineson \& Peel (in press). Adjacent to the Nordenskiöld Fjord Jungersen Gletscher line (see fig. 1), the Brønlund Fjord Group is subdivided into the Aftenstjernesø Formation and an overlying, new formation. The nature and relationship of this formation are not yet known in sufficient detail to justify its placement in the figure.

Age. In the type area, fossils indicate an age range from Early to early Late Cambrian, although body fossils have not been collected from the upper quarter of the group. Early Ordovician conodonts occur below correlatives of the overlying Permin Land Formation in Daugaard-Jensen Land (see Bryant \& Smith, 1985), suggesting that the Ryder Gletscher Group may also range into the Ordovician.

Correlation. The Ryder Gletscher Group correlates in terms of geological age with the Kastrup Elv and Telt Bugt Formations and most of the overlying Cass Fjord Formation of Daugaard-Jensen Land (Washington Land) to the west, and with the Brønlund Fjord Group and much of the Tavsens Iskappe Group of Peary Land to the east (Peel, 1982; fig. 3).

\section{Formation RG1}

This formation forms a grey to dark grey weathering unit up to $65 \mathrm{~m}$ in thickness at the base of the Ryder Gletscher Group. Coarse, sometimes cross-bedded limestone grainstones dominate, but micrites are prominent at a locality east of C. H. Ostenfeldt Gletscher. Hardgrounds occur within the middle of the formation. Rich, but often comminuted, faunas of olenellid and eodiscid trilobites, and brachiopods indicate an Early Cambrian age. 


\section{Formation $R G 2$}

Formation RG2 consists of about $105 \mathrm{~m}$ of often coarsely recrystallised dolomites with yellow-brown to rusty red weathering colours. A basal breccia unit passes up into cross-bedded 'grainy' dolomites, while a dark brownish, grey mottled dolomite forms the top unit of the formation (fig. 2A). No fossils have been recovered.

\section{Formation RG3}

The alternation of very pale weathering cryptalgal laminated dolomites and darker, greybrown burrow mottled dolomites makes this unit (thickness about $70 \mathrm{~m}$ ) a distinctive mapping horizon in southern Wulff Land and Warming Land (fig. 2A). No fossils were observed.

\section{Formation RG4}

Formation RG4 (fig. 2A; thickness about $110 \mathrm{~m}$ ) is dominated by dark grey brown, burrow mottled dolomite. A thick, pale weathering bed of sucrosic dolomite, containing digitate stromatolites, forms a prominent horizon in the middle of the formation in south-west Wulff Land. No fossils were found.

\section{Formation RG5}

This formation consists of almost $100 \mathrm{~m}$ of somewhat irregularly bedded, grey micritic limestones with shaley partings producing a greenish wash. The micrites are interbedded with dolomitised horizons of digitate stromatolites. A cliff-forming, dark brown weathering limestone forms the top unit of the formation. Trilobites occur sporadically and suggest a Middle Cambrian age (Palmer in Peel, 1980).

\section{Formation RG6}

This formation attains a thickness of almost $200 \mathrm{~m}$ in south-west Wulff Land but is often poorly exposed. Dolomitised micrites and micritic limestones are typical, often with thin flake breccias. Fine-grained, wave rippled thin sandstone beds occur near the top of the formation, and a distinctive unit of green and purple siltstones and pale dolomites forms a conspicuous horizon at this level. The micritic limestones compare well with similar rocks in the Cass Fjord Formation of Daugaard-Jensen Land to the west (Henriksen \& Peel, 1976; Palmer \& Peel, 1981). Trilobites from the lower part of formation RG6 indicate a Dresbachian (early Late Cambrian) age (Palmer in Peel, 1980).

\section{Brønlund Fjord Group of Freuchen Land}

The four formations comprising this group in the J. P. Koch Fjord area (figs $1 \& 3$ ) were briefly characterised by Ineson \& Peel (1980) and are defined by Ineson \& Peel (in press). 
The Aftenstjernesø Formation can be readily traced as a lighter coloured cliff-forming unit between the dark recessive shales forming the top of the Buen Formation, below, and the dark, recessive shales and carbonates of the Henson Gletscher Formation, above, as far west as Jungersen Gletscher - Nordenskiöld Fjord (fig. 2B). Immediately to the south-west of this line, the Henson Gletscher Formation is not present and the Aftenstjernes $\emptyset$ Formation is overlain by a thick unit of darker brown weathering dolomite, the new formation of the Brønlund Fjord Group mentioned above. A few kilometres further to the south-west, distinction between even these two units is apparently not possible on weathering characteristics. From the air the inaccessible outcrops appear massive, without the thin, nodular bedding characteristic of the Aftenstjernes $\emptyset$ Formation in its type area around J. P. Koch Fjord.

A distinctive feature of the Aftenstjernes $\varnothing$ Formation in this area is a basal, thin bed of black-weathering micritic limestone clearly visible in the steep cliffs. This unit occurs both to the south-west and north-east of the Nordenskiöld Fjord - Jungersen Gletscher line and is considered equivalent to formation RG1 of the Ryder Gletscher Group, described above. Formation RG1 is usually composed mainly of coarse grainstones, but micritic limestones are dominant in outcrops east of C. H. Ostenfeldt Gletscher.

The remainder of the Aftenstjernes $\varnothing$ Formation is apparently laterally contiguous with formation RG2 and the lower part of formation RG3 of the Ryder Gletscher Group.

The Henson Gletscher Formation thickens from $62 \mathrm{~m}$ at the type section at J. P. Koch Fjord to $120 \mathrm{~m}$ in south-west Freuchen Land. The formation is absent to the south-west of the Nordenskiöld Fjord - Jungersen Gletscher line. The abruptness of its disappearance is such that the formation is present along the north and east sides of Jungersen Gletscher but is absent, except for a few thin whisps of dark sediment only $4 \mathrm{~km}$ away, on the south-west wall of the glacier (fig. 2B). Despite its increased thickness, the formation as developed in south-west Freuchen Land is lithologically very similar to the type sequence, some $35 \mathrm{~km}$ to the north-east.

The Henson Gletscher Formation in south-west Freuchen Land is sharply overlain by pale weathering breccias and sucrosic dolomites of the Sydpasset Formation, which form a thin, cliff-forming unit with a pronounced uneven top. Maximum observed thickness was about 35 $\mathrm{m}$, but the normal thickness is most probably only half this amount. Immediately to the north-east of Jungersen Gletscher, the pale sucrosic dolomite forms isolated masses on a hundred metre scale, apparently in normal sedimentary contact with the underlying Henson Gletscher Formation. The masses are juxtaposed with coarse dolomite breccia containing blocks of the same sucrosic dolomite. Lateral contacts between the two lithologies are often steep, and the masses of sucrosic dolomite seem to form points of high relief on the upper surface of the formation. Where examined, the contact between the masses of pale sucrosic dolomite and the underlying dark dolomites of the Henson Gletscher does not show major disruption, although slump-deformation is quite widespread within the latter formation. It was not possible, however, to conclusively ascertain if the pale sucrosic dolomite masses were rafts of consolidated sediment which have been transported down slope from source, or if they represent in situ relics of a former continuous sheet of carbonate grainstone, most of which has been stripped away as a component of the associated breccia flow. Both processes may be reasonably expected to have occurred.

The Ekspedition Bræ Formation is generally recessive and poorly exposed in south-west Freuchen Land. A few kilometres north-east of the Nordenskiöld Fjord - Jungersen Gletscher line, a section some $70 \mathrm{~m}$ thick is predominantly composed of dark grey-green 
shales. The type section at J. P. Koch Fjord preserves a sequence some $82 \mathrm{~m}$ thick, dominated by pale weathering, thin-bedded, grey lime mudstones with shale interbeds: the lime mudstone beds are only sporadically developed in the south-west Freuchen Land section. The Ekspedition Bræ Formation thins out entirely as Nordenskiöld Fjord is approached, disappearing laterally between two prograding tongues of the previously mentioned new formation.

\section{Tavsens Iskappe Group of Freuchen Land}

The Tavsens Iskappe Group is well exposed along Navarana Fjord where the largely inaccessible cliffs clearly show the three formations recognised by Ineson \& Peel (1980) and Ineson \& Peel (in press) in the J. P. Koch Fjord area (figs 1 \& 3). Outcrops to the south-west of the head of Navarana Fjord are imperfect, but the base of the group can be mapped for a few kilometres to the south-west of the Nordenskiöld Fjord - Jungersen Gletscher line. Intervening ice caps prevent study of the lateral transition of formations of the Tavsens Iskappe Group into the laterally equivalent but lithologically dissimilar formations of the Ryder Gletscher Group.

\section{References}

Bryant, I. D. \& Smith, M. P. 1985: Lowermost Ordovician sandstones in central and western North Greenland. Rapp. Grønlands geol. Unders. 126, 25-30.

Dawes, P. R. 1976: Precambrian to Tertiary of northen Greenland. In Escher, A. \& Watt, W. S. (edit.) Geology of Greenland, 248-303. Copenhagen: Geol. Surv. Greenland.

Henriksen, N. \& Peel, J. S. 1976: Cambrian - Early Ordovician stratigraphy in south-western Washington Land, western North Greenland. Rapp. Grønlands geol. Unders. 80, 17-23.

Hurst, J. M. \& Peel, J. S. 1979: Late Proterozoic(?) to Silurian stratigraphy of southern Wulff Land, North Greenland. Rapp. Grønlands geol. Unders. 91, 37-56.

Ineson, J. R. \& Peel, J. S. 1980: Cambrian stratigraphy in Peary Land, eastern North Greenland. Rapp. Grønlands geol. Unders. 99, 33-42.

Ineson, J. R. \& Peel, J. S. in press: Cambrian shelf stratigraphy of the Peary Land region, central North Greenland. Bull. Grønlands geol. Unders.

Palmer, A. R. \& Peel, J. S. 1981: Dresbachian trilobites and stratigraphy of the Cass Fjord Formation, western North Greenland. Bull. Grønlands geol. Unders. 141, 46 pp.

Peel, J. S. 1979: Cambrian - Middle Ordovician stratigraphy of the Adams Gletscher region, south-west Peary Land, North Greenland. Rapp. Grønlands geol. Unders. 88, 29-39.

Peel, J. S. 1980: Cambrian and Ordovician geology of Warming Land and southern Wulff Land, central North Greenland. Rapp. Grønlands geol. Unders. 101, 55-60.

Peel, J. S. 1982: The Lower Palaeozoic of Greenland. Mem. Can. Soc. Petrol. Geol. 8, 309-330.

Peel, J. S. \& Christie, R. L. 1982: Cambrian-Ordovician platform stratigraphy: correlations around Kane Basin. In Dawes, P. R. \& Kerr, J. W. (edit.) Nares Strait and the drift of Greenland: a conflict in plate tectonics Meddr Grønland, Geosci. 8, 117-135. 